\title{
Uncinial patterns and age determination in terebellid polychaetes
}

\author{
J. C. Duchêne, M. Bhaud \\ Université P. et M. Curie, Laboratoire Arago, F-66650 Banyuls/mer, France
}

\begin{abstract}
This work seeks morphological criteria for estimating age and hence for demographic population studies. Observations on 6 species of terebellid polychaetes revealed a continuous formation of uncinial plates throughout the individual's life. As the replacement proceeds, the size of uncinial plates increases and the torus bears larger and larger uncinial plates between the area where they appear and where they are shed. The rate of size increase is not constant; it is pronounced in young stages but progressively slows with age. Consequently, difference in size between uncinial plates of both extremes of a particular torus varies during the polychaete's life span. Uncinial distribution along the thorax shows the effect of change from a single to a double row. There is either retention of the same number of uncini (Neoleprea), doubling of the number (Lanice) or a middle increase (Eupolymnia).
\end{abstract}

\section{INTRODUCTION}

A major problem arising during the demographic analysis of a polychaete population is the choice of parameters to be measured. These parameters must, for a given age, present a minimum variability. Generally, the first phases of a demographic study establish a set of size frequency histograms. Growth parameters most often used are dry weight, fresh weight and linear body dimensions, such as length or cross section (Desbruyères 1976, 1977, Duchêne 1982b). The number of segments is less used, because segment number increases during the life span: the number of added segments varies with species and may be fixed very early or increase at different rates during the life span. These parameters must be manipulated with extreme care because of possible autotomy, regeneration of posterior segments, or body contractions of fixed materials. In order to limit errors due to body autotomy, Lang (1984) and Grémare (1986) used thoracic weights of the terebellid Eupolymnia nebulosa.

Although the hard structures of Errantia jaws have long been used for age determination (Kirkegaard 1970, Escourt 1975, Rétière 1976, Olive 1977, 1980 for Nephtyidae; Valderhaug 1985 for Lumbrineridae), they cannot be used in sedentary polychaetes, as - with the exception of Gnathampharete paradoxa (decribed by Desbruyères 1978) - these have no jaws. The only hard structures available are uncinigerous plates which, to our knowledge, have never been used for this purpose. The process of renewal of setae in Polychaeta is not well understood, although there are some studies on the specialized setae of Chaetopteridae (Bhaud 1979), the paleae of Sabellariidae (Gruet 1986) and the setae of Terebellidae (Bhaud \& Grémare 1988b).

The purpose of this paper is to show how, in some terebellid species, number and size of uncinial plates vary during body development and ageing. The development of these species has previously been studied (Duchêne 1979, 1982a, 1983, 1988, Bhaud \& Grémare 1988a).

Data on uncinial plates are generally not reported in the literature, and Holthe (1986), in his monograph on terebellomorph polychaetes, gave no information about uncinial plate development at the individual scale, but only discussed the phyletic evolution of the morphology of uncinial plates within the order.

\section{MATERIAL AND METHODS}

Biometric measurements were carried out on the following terebellid species: Thelepus setosus (Quatrefages, 1865) and Neoleprea streptochaeta (Ehlers, 1897), sampled in the Golfe du Morbihan, Kerguelen archipelago (Subantarctic Province) (Duchêne 1979, 1982a); and on Eupolymnia nebulosa (Montagu, 1818) collected at Banyuls-sur-mer in the western Mediterranean (Bhaud \& Grémare 1988a). Former data on Lanice conchilega (Pallas, 1766) and on 2 species of the genus Pista (P. cristata and P. cretacea) collected at Banyuls- 
sur-mer were added in order to increase the spectrum of this analysis.

Terebellids are tubicolous worms with the body divided into 2 regions. The head bears numerous foodgathering tentacles, each with a ciliated groove. The thorax has biramous segments: notosetae are winged capillaries and neurosetae are uncinial plates of various morphology. The abdomen exhibits only neuropodia with uncinial plates.

On Thelepus setosus, uncini are always in a single row, starting at Segment 5 (Setiger 3); there is no strict difference between thorax and abdomen because notosetae continue two-thirds along the abdomen. In Eupolymnia nebulosa, notopodial capillaries spread over 14 segments, starting at the 4 th. The uncini, starting on Segment 5, are set in a single row (Segments 5 to 10 ), then in a double row on the posterior thorax (Segments 11 to 21). In Neoleprea streptochaeta, the thorax is 17 setigers long. The first 2 segments lack setae; thoracic uncini are in a single row in the first 8 segments, then in a double row in the last thoracic segments. Lanice conchilega has notopodial capillary setae over 17 segments, from Segments 4 to 20 . Uncini are first in a single row from Segments 5 to 10, then in 2 rows, back to back, from Segments 11 to 20 .

For all species, measurements were made on the 8 th setigerous segment. It corresponds generally to the widest body diameter (from former population studies). In a large individual, the segment was dissected, placed in pure lactic acid and immediately observed under a microscope. Counting the number of regularshaped uncini is simple. Developing uncini are not taken into consideration. Size measurements are made at $100 \times$ magnification under oil immersion. For a single row, measurements at the 2 extremities are not sufficient, as the plates vary irregularly in size. Fig. 1 (A to E) gives the parameters used for the biometrical study. The complete row is measured. Linear regressions were derived using uncinus position against uncinus size. Slope reflects the asymmetry of the torus, related to the addition of bigger uncini.

When the individual is small (Thelepus setosus or Eupolymnia nebulosa), it is squashed between microscope slides and, in the case of E. nebulosa, the first torus with alternate uncini is located. The uncinial plates are counted and measured with an immersion objective, and for interpretation of quantitative data it is necessary to identify left and right parapodia as well as the orientation of neuro- and notopodia. In each parapodium, setae are located dorsal to the uncinal plate. The uncinial row takes the form of a ridge extending towards the medioventral axis
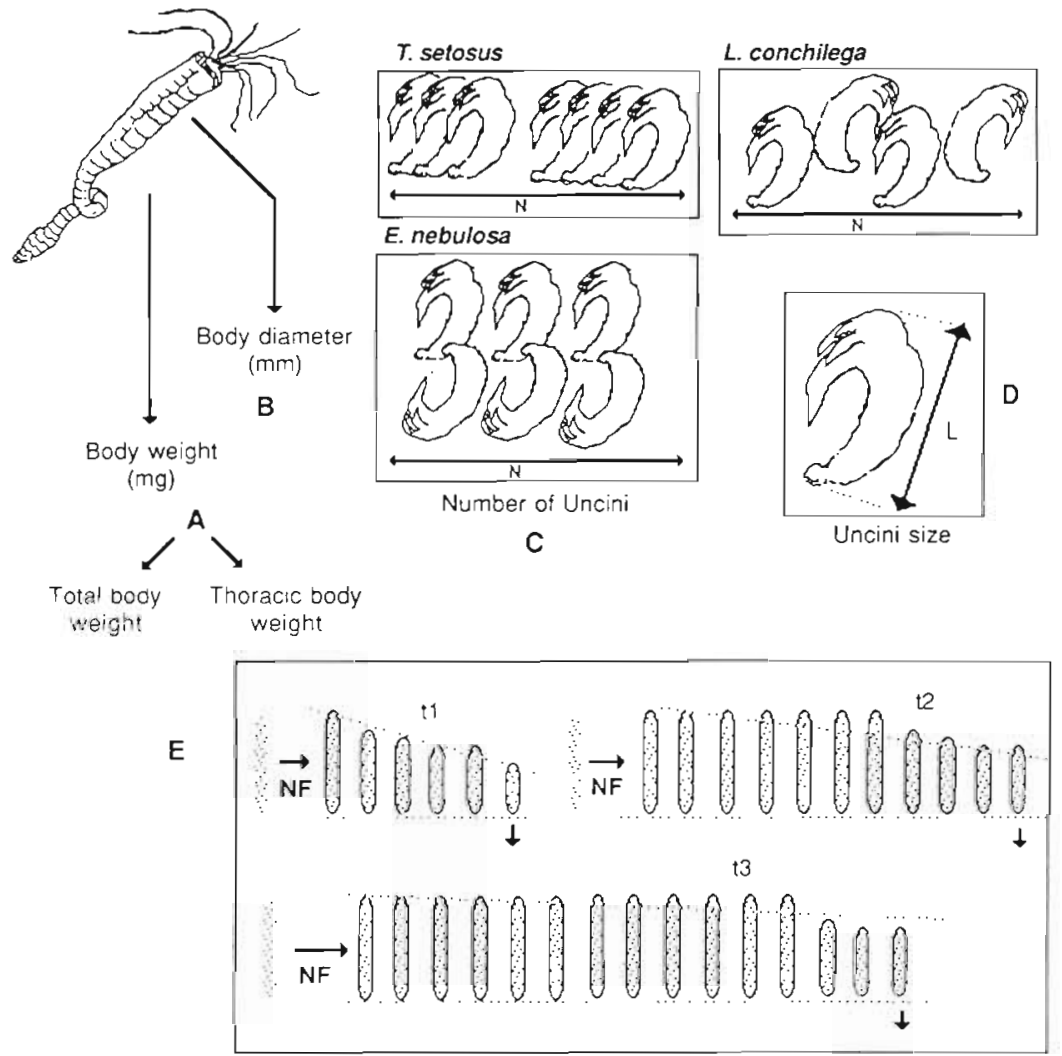

Slope of uncini rows
Fig. 1. Thelepus setosus and Eupolymnia nebulosa. Parameters used for biometrical study. (A) Body fresh weight, including thoracic and total body weight. (B) Body diameter, across the 8 th setigerous segment. (C) Number of uncini in row (always in a simple torus for $T$. setosus and with altemate torus in $E$. nebulosa). (D) Measuring size of uncini. (E) Schematized change of slope of uncinial plates on the 8th setigerous segment at 3 different times; this slope is used as a growth index of torus; 11 : young individuals, with different uncinial sizes; $t 2$ : older individuals with few maximum sized uncini (in $T$ setosus ): $\mathrm{t} 3$ : older individuals with numerous maximum sized uncini. NF = newly formed uncini; $\rightarrow=$ addition,$\downarrow=$ shedding of uncini 


\section{RESULTS}

\section{Thelepus setosus}

Organization of the uncinial row

In larval stages, the first pair of uncini becomes visible on the fourth distinct body segment ca $14 \mathrm{~d}$ after spawning (Table 1). From that stage on, the development of the uncini row is fast and at Day 19,4 pairs of uncini are present from body Segments 5 to 8 . The recorded uncinial size is then $12.3 \mu \mathrm{m}$. The uncini remain in single rows throughout the life span of Thelepus setosus.

On adults, uncini occur from the 3rd setigerous segment (body Segment 5), in a simple retrogressive row, down to the pygidium. After Segments 35 to 40 uncinial tori take the shape of prominent rectangular pinnules. A description of the uncinial plates can be found in Duchêne (1982a).

\section{Growth of the uncinial rows}

Close examination of uncinial rows reveals a dynamic modification of the number and shape of the uncini. Although uncini are important in taxonomy, it appears these are only stable in the adults. It seems likely that the polychaete produces new uncini throughout its life. This has been observed in other polychaetes, particularly by Gruet (1983) in Sabellaria alveolata: opercular setae as well as parathoracic setae are shed at a rate comparable to the body growth rate.

In Thelepus setosus uncini production data is not known, but indirect observations were made during overall population studies (Duchêne 1982a, 1985). On larger individuals, forming uncini are always observed; this indicates that uncinial renewal is not limited in time. The size of uncini produced increases from larval life until complete maturity. New uncini are added on one side of the row, older ones eliminated on the other side of the row. The slope of the torus is calculated and used as an uncinial growth index (Fig, 2B): size of individual uncini vs position of the uncini within the torus is used in a linear regression to calculate the slope. The result of the continuous uncinial production is a constant and regular modification of the slope of the uncinial row from late larval to mature stages.

In very young individuals, there is an increase of the slope of the regression, related to constant addition of larger uncini. The size of newly formed uncini changes very rapidly within a few days. The minimum size recorded for the uncini was $12.3 \mu \mathrm{m}$ (for a single pair of uncini of a 4 -setiger metatrochophore). In late larvae, variation in uncini size may be found, depending on the segment observed. In a 7 -setiger larva, 2 newly formed uncini found on Setiger 5 measured 21 and $33 \mu \mathrm{m}$, whereas a single older uncinus found on Setiger 3 measured $42 \mu \mathrm{m}$ and was placed next to 2 limbate and 1 spatulate setae. On a 9 -setiger larvae, the smallest observed incinus on the last body segment was $10 \mu \mathrm{m}$ long and apparently not complete (basal part incomplete). The size of these uncini is subject to rapid variation in relation to the fast body growth of the very young individuals and the necessity for functional structures, which are used by the larvae to settle on the sediment.

The next step is an inversion of the process, when large uncini become predominant. From that stage until complete elimination of the younger uncini, the slope decreases slowly and finally, when only adulttype uncini are added to the row, the slope is equal to

Table 1 Thelepus setosus. Number of setae and uncini in newly hatched individuals sampled at 3 different times during larval development. Club-shaped setae are first to appear and are progressively shed and replaced by limbate setae. The appearance of uncini corresponds closely to attempts by larvae to settle and build their first tube. Prostomium not counted. Only distinct larval segments shown: a new achaetous segment is later added between prostomium and first body segment

\begin{tabular}{|c|c|c|c|c|c|c|c|c|c|}
\hline \multirow{2}{*}{$\begin{array}{l}\text { Days after } \\
\text { spawning }\end{array}$} & \multirow[t]{2}{*}{ Appendage } & \multicolumn{8}{|c|}{ Distinct body segment number } \\
\hline & & $1+2$ & 3 & 4 & 5 & 6 & 7 & 8 & 9 \\
\hline \multirow[t]{4}{*}{8} & Setae & & & & & & & & \\
\hline & Limbate & 0 & 0 & 0 & 0 & 0 & 0 & 0 & 0 \\
\hline & Club-shaped & 0 & 1 & 0 & 0 & 0 & 0 & 0 & 0 \\
\hline & Uncini & 0 & 0 & 0 & 0 & 0 & 0 & 0 & 0 \\
\hline \multirow[t]{4}{*}{16} & Setae & & & & & & & & \\
\hline & Limbate & 0 & 1 & 1 & 1 & 0 & 0 & 0 & 0 \\
\hline & Club-shaped & 0 & 1 & 1 & 1 & 1 & 0 & 0 & 0 \\
\hline & Uncini & 0 & 0 & 0 & 1 & 0 & 0 & 0 & 0 \\
\hline \multirow[t]{4}{*}{19} & Setae & & & & & & & & \\
\hline & Limbate & 0 & 2 & 2 & 1 & 1 & 0 & 0 & 0 \\
\hline & Club-shaped & 0 & 1 & 1 & 1 & 1 & 0 & 0 & 0 \\
\hline & Uncini & 0 & 0 & 0 & 1 & 1 & 1 & 1 & 0 \\
\hline
\end{tabular}


A
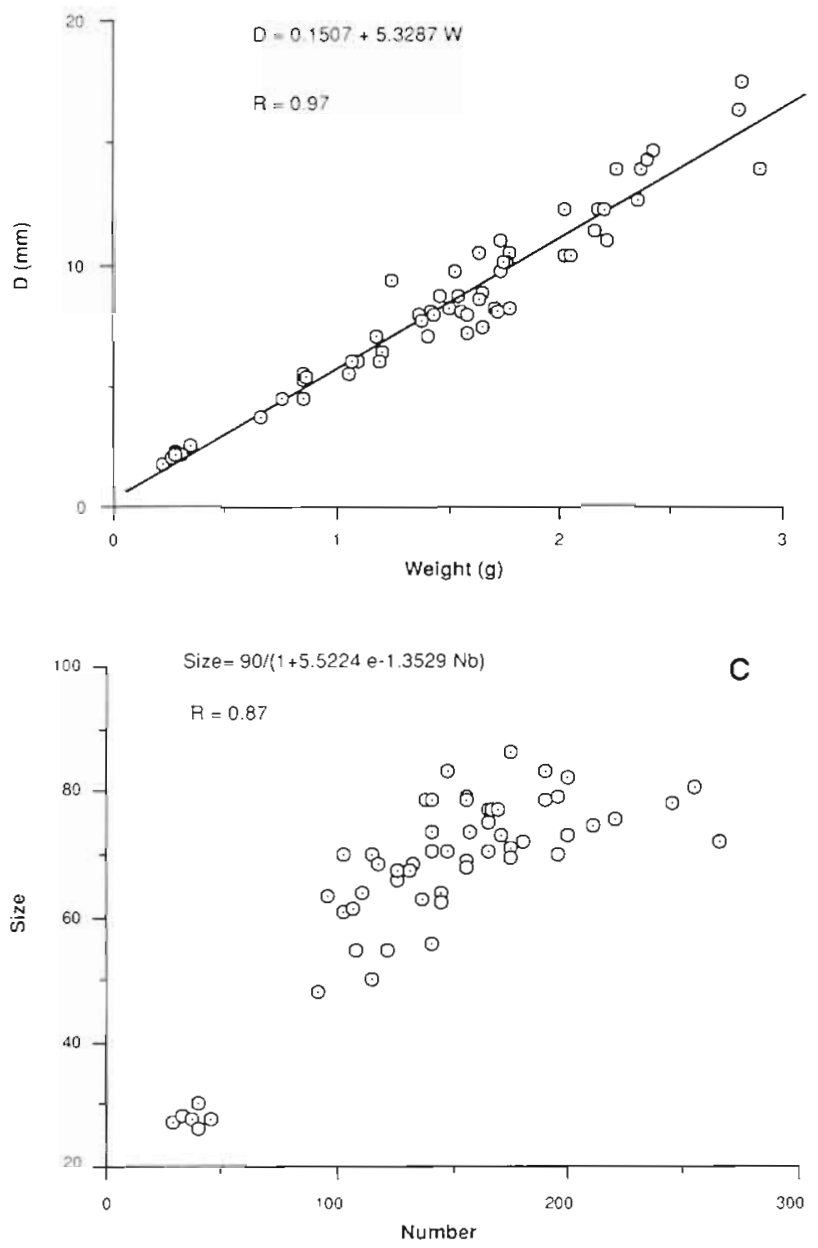

B
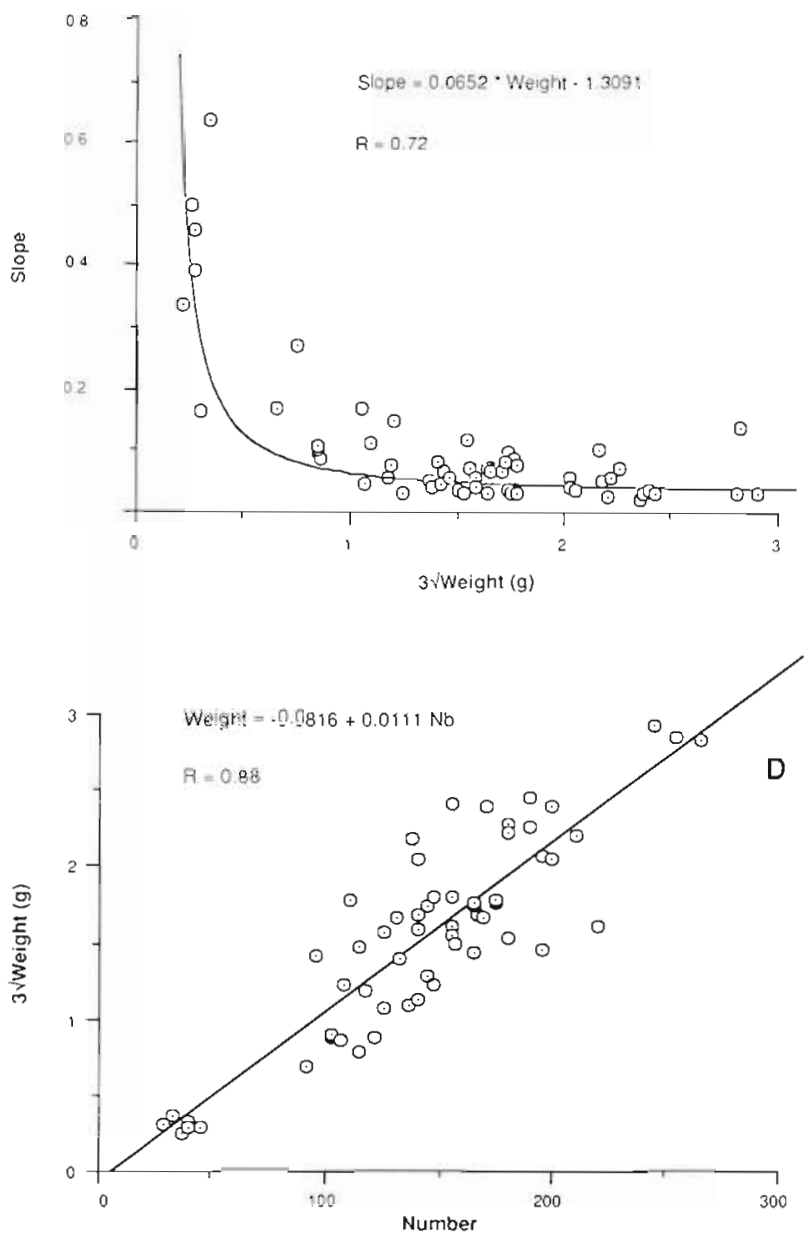

Fig. 2. Thelepus setosus. Biometric measurements. (A) Correlation between body diameter (across 8 th setiger) and total fresh weight. (B) Correlation between slope of uncinial torus of 8 th setigerous segment (measured by deriving a linear regression using uncini position and size) and body weight. (C) Relation between size and number of uncini on 8th setiger. Best fit corresponds to sigmoid curve. Maximum size is reached when number of uncini per torus is still increasing. (D) Relation between fresh weight and number of uncini on 8 th setiger torus

zero. Fig. 2B illustrates the change in the slope in relation to body dry weight. The observations are related to age throughout the population studies, involving the use of dry and fresh weight measurements and body diameter measurements - the latter being more convenient and highly correlated to the former (Fig. 2A). Age can thus be estimated from previous population studies (Duchêne 1979, 1982b).

Observations on the number of uncini in a row reveal further information (Fig. 2D). The number of uncini in a row increases with body size and age (Table 2). The measured number of uncini in a row is the result of the balance between newly created uncini and lost uncini. The increase in uncini number with age (using the agecorrelated weight growth) seems to be fairly constant, as shown by Fig. 2D, and this presupposes that the ratio of created/lost uncini is constant for a given metabolism and is positive for the Kerguelen populations. If we use the results of population studies (Fig. 3A, B), then it appears that the numbers of created uncini for individu-

Table 2. Thelepus setosus. Number and size of uncini on 8 th body segment in terms of age; confidence intervals at $95 \%$ level

\begin{tabular}{|cccc|}
\hline $\begin{array}{c}\text { Age } \\
(\mathrm{yr})\end{array}$ & Number $\pm \mathrm{SD}$ & $\begin{array}{c}\text { Size } \\
(\mu \mathrm{m})\end{array}$ & $\pm \mathrm{SD}$ \\
\hline 0 & $31.67 \pm 4.75$ & 25.88 & \pm 1.09 \\
1 & $101.67 \pm 31$ & 49.41 & \pm 6.26 \\
2 & $128.54 \pm 21.34$ & 62.04 & \pm 5.08 \\
3 & $150.73 \pm 15.14$ & 71.01 & \pm 3.30 \\
4 & $157.50 \pm 15.19$ & 71.31 & \pm 3.11 \\
5 & $172.7 \pm 29.93$ & 71.24 & \pm 3.34 \\
6 & 250 & 75.22 & \\
\hline
\end{tabular}


als hatched the same year in the Gulf of Morbihan vary depending on location of the population and corresponding local growth rate.

Biometrics dealing with number of uncini in a row vs medium uncinial size show that there is a constant increase in the size of the uncini in a row until the third year, followed by a steady state and a plateau in the older individuals, where a maximum size $(71 \mu \mathrm{m}$ average) seems to be obtained (Fig. 2C).

\section{Eupolymnia nebulosa}

Organization of the uncinial row

Three findings emerge from a detailed description of the progressive organization of uncini and setae at larval stage (Bhaud 1988). (1) Club-shaped setae are the

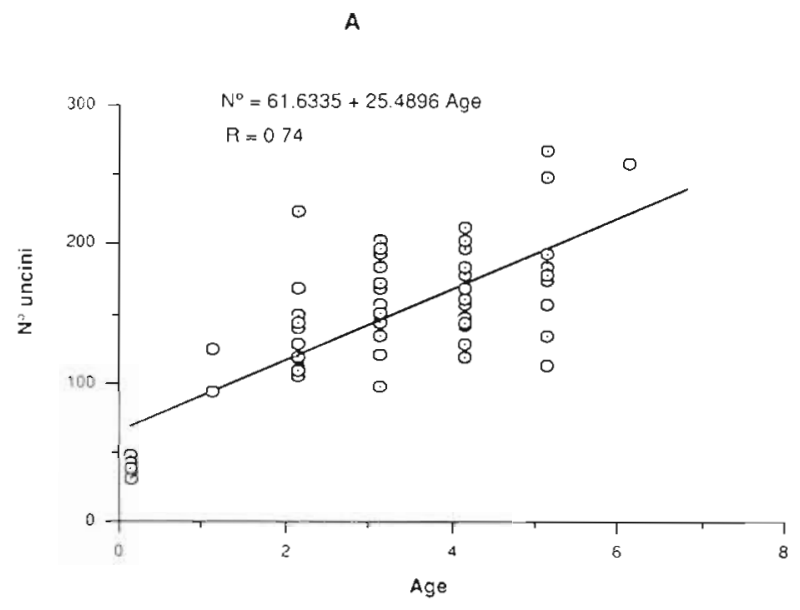

B

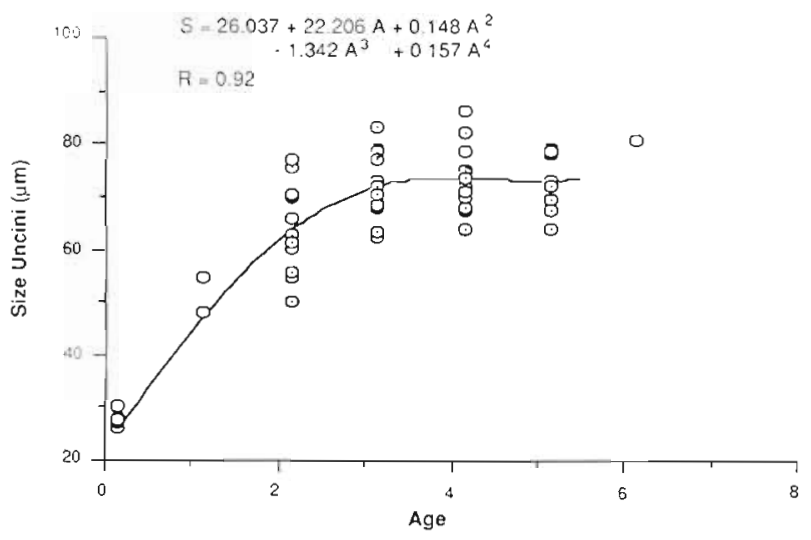

Fig. 3. Thelepus setosus. (A) Relation between number of uncini and age of individuals on the 8th setiger torus. (B) Relation between medium size of uncini and age of individuals; uncinial growth seems to stop after $3 \mathrm{yr}$, but new uncini are still added to rows first to appear on Segment 3 to 8 (Table 3); (2) limbate and club-shaped setae appearing on the third body segment (or first larval setigerous segment) are shed; (3) the first uncinus appearing on the 4 th body segment (or 2nd larval setigerous segment) is shed (Table 4).

The formation of uncigerous tori has been described by Bhaud \& Grémare (1988b). In the adult, uncini start on body Segment 5 and from Segments 5 to 10 are set on a simple row; on each torus the main fang is directed forwards. The direction of the fang alternates from Segment 11. Growth of uncinal plates has been observed in the 1st segment bearing alternating uncini (Segment 11), which is the 9th setiger in the larva and the 8 th in the adult.

\section{Development of the torus}

The development of the torus has never been observed in Eupolymnia nebulosa, and among studies on Terebellidae, observations are scarce. As regards Nicolea zostericola, Herpin (1925) noted that partly alternating sets of uncini become fully alternate after the loss of older, smaller uncini. Eckelbarger (1974), working with the same species, reported that uncini appear first on setigerous Segments 3 and 4 , later on other segments and are located ventral to the capillary setae; but no data are available on the regular substitution of uncini on a given torus.

In Eupolymnia nebulosa, the first uncini are in a retrogressive position, the main fang being oriented towards the head (Fig. $1 \mathrm{C}$ ). The first uncinus, in a progressive position with the main fang oriented backward, appears when juveniles are about $48 \mathrm{~d}$ old. One uncinus out of two takes this orientation. This alternating position is at first partial, beginning in the dorsal part of the torus and then spreading toward the ventral side. When the last uncini to appear reach $18 \mu \mathrm{m}$ their alternating position becomes visible. Once this generally alternating position has been achieved, it is still possible to find 2 uncini side by side with the same direction.

Relations between number, length and, if possible, age have been established in Eupolymnia nebulosa. The number of measurements is relatively limited. A relation is first computed, at the level of the 1st setiger showing alternate uncinial plates, between number and mean uncinial plate size (Fig. 4).

\section{Additional measurements}

Additional measurements made on Neoleprea streptochaeta from Kerguelen and on Lanice conchilega from Banyuls reveal some information on the trends of the uncinial distribution in these 4 terebellid species 
Table 3. Eupolymnia nebulosa. Number of larval setae and uncini in young individuals observed in cocoon or after hatching from the mucous bag

\begin{tabular}{|c|c|c|c|c|c|c|c|c|c|}
\hline \multirow{2}{*}{$\begin{array}{l}\text { Days after } \\
\text { spawning }\end{array}$} & \multirow[t]{2}{*}{ Appendage } & \multicolumn{8}{|c|}{ Distinct body segment number } \\
\hline & & 3 & 4 & 5 & 6 & 7 & 8 & 9 & 10 \\
\hline \multirow[t]{4}{*}{3} & Setae & & & & & & & & \\
\hline & Limbate & 0 & 0 & 0 & 0 & 0 & 0 & 0 & 0 \\
\hline & Club-shaped & 1 & 0 & 0 & 0 & 0 & 0 & 0 & 0 \\
\hline & Uncini & 0 & 0 & 0 & 0 & 0 & 0 & 0 & 0 \\
\hline \multirow[t]{4}{*}{10} & Setae & & & & & & & & \\
\hline & Limbate & 1 & 0 & 0 & 0 & 0 & 0 & 0 & 0 \\
\hline & Club-shaped & 1 & 1 & 0 & 0 & 0 & 0 & 0 & 0 \\
\hline & Uncini & 0 & 0 & 0 & 0 & 0 & 0 & 0 & 0 \\
\hline \multirow[t]{4}{*}{17} & Setae & & & & & & & & \\
\hline & Limbate & 1 & 1 & 1 & 1 & 1 & 1 & 1 & 0 \\
\hline & Club-shaped & 1 & 1 & 1 & 1 & 1 & 1 & 0 & 0 \\
\hline & Uncini & 0 & 1 & 1 & 1 & 1 & 1 & 1 & 1 \\
\hline \multirow[t]{4}{*}{36} & Setae & & & & & & & & \\
\hline & Limbate & 0 & 4 & 4 & 3 & 5 & 4 & 4 & 3 \\
\hline & Club-shaped & 0 & 1 & 1 & 1 & 0 & 0 & 0 & 0 \\
\hline & Uncini & 0 & 0 & 2 & 1 & 2 & 2 & 1 & 0 \\
\hline
\end{tabular}

Table 4. Thelepus setosus and Eupolymnia nebulosa: setal and uncinial distribution in the first segments of larvae and adults. In E. nebulosa a segment shift is possible during larval life in the case of setal and uncinial loss or a modification of anterior segmentation

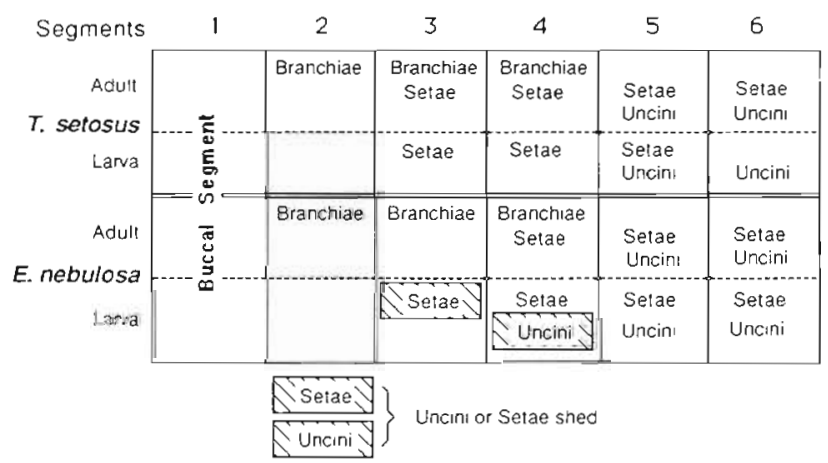

(Fig. 5). The largest number of uncini in a single row seems to be located in the anterior part of the body, within the first 20 setigerous segments. In Thelepus setosus this roughly corresponds to the widest body cross-section. As the number of uncini on a torus increases during the life span, an upward shift of the curves for different individuals of $T$. setosus of increasing age is normal. The same observation applies for Eupolymnia nebulosa. The formation of alternate rows on the thoracic part of $N$. streptochaeta, E. polymnia and $L$. conchilega is somewhat confusing: if one considers the number of uncini on the abdominal segment, these relatively weak values correspond to a general
A

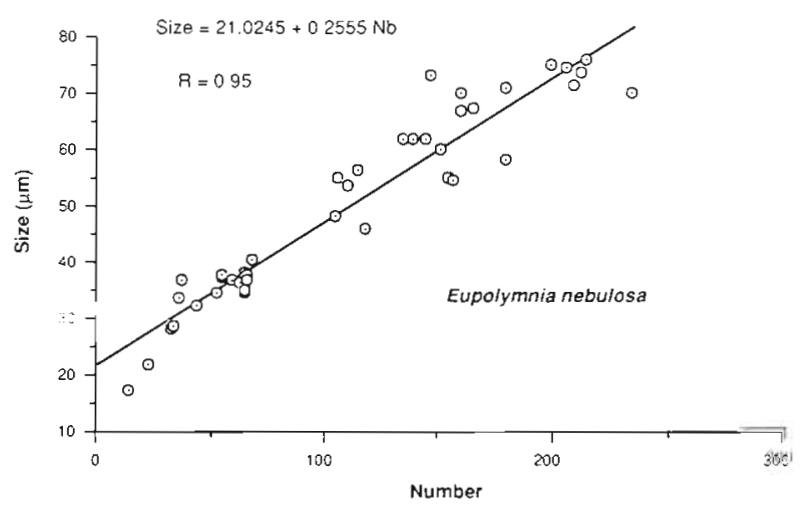

B

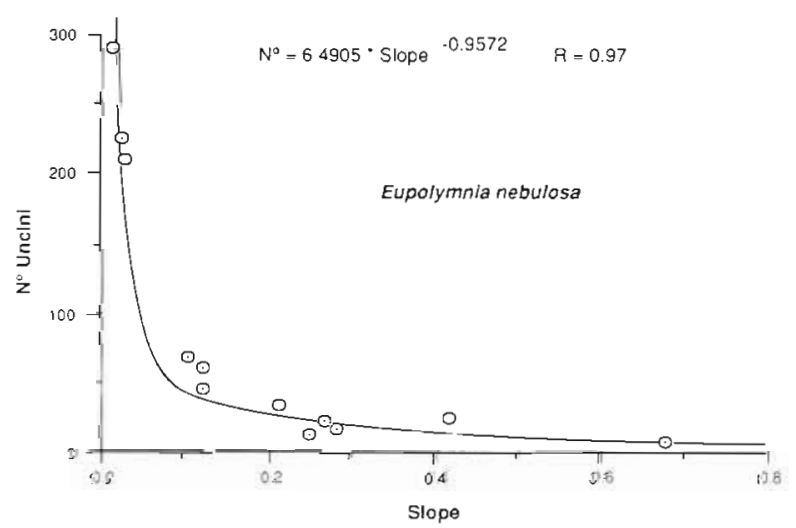

Fig. 4. Eupolymnia nebulosa. Biometric measurements. (A) Relation between mean length and number of uncinial plates. (B) Relation between slope of torus and number of uncini 
posterior decrease, found also in $T$. setosus, where uncinial rows remain simple all along the body.

Thus, considering averages on different species, the location within a species of the widest torus to be measured differs slightly. This must be taken into consideration when using these parameters for biometric purposes. A preliminary study, involving systematic measurements of anterior uncinial rows on individuals of different sizes, will yield information on the segment to be used.

Another interesting point is the formation of alternate rows on a number of body segments. Fig. 6 shows the average number of uncini on the anterior part of 4 species of terebellid annelids. For the 3 species with alternate rows, there are important differences with Neoleprea streptochaeta, Eupolymnia nebulosa on one hand, and Lanice conchilega on the other. In the first 2 species, appearance of alternate rows corresponds to a decrease in the number of uncini in each row. In $L$. conchilega the occurrence of an alternate row is not related to this marked decrease in the number of uncini in the alternating row. The results of these 2 trends are related to the modification of the tori from single to alternate, and to the possible formation of alternate tori: (1) In $N$. streptochaeta and E. nebulosa, the total increase of uncini in the alternating rows is balanced
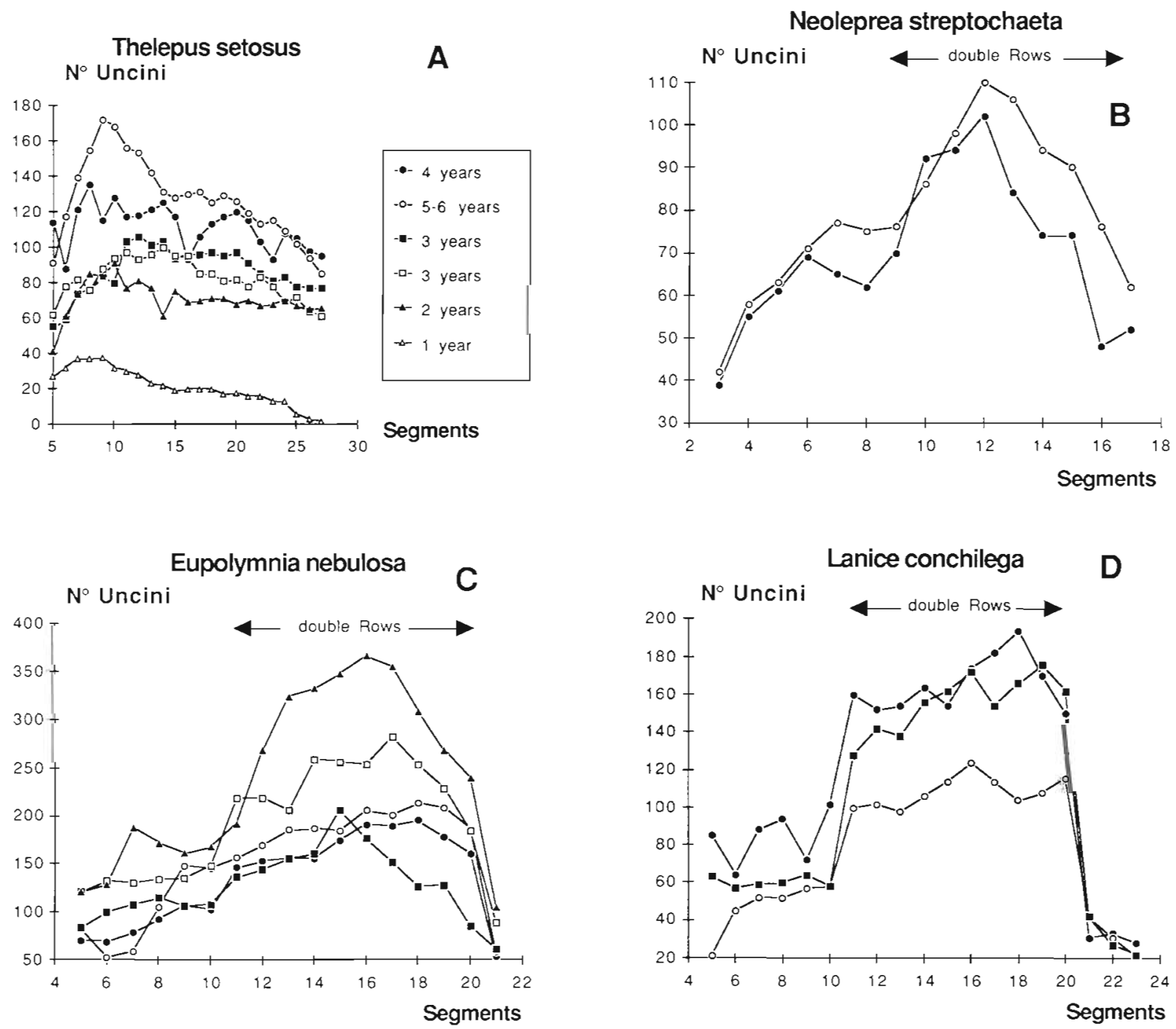

Fig. 5. Number of uncini in anterior setigerous segments of 4 species of terebellid polychaetes. (A) Different curves for Thelepus setosus of 6 different sizes reflect uncinial growth with age; lower curve: a 1 yr old individual; upper curve: torus of 5 to 6 yr old individual. (B) In Neoleprea streptochaeta uncini measured on 2 individuals start on 3rd setigerous segment and are alternated after 8th segment. (C) In Eupolymnia nebulosa maximum number of uncini per torus is found on Segments 15 to 18. Measurements made on 5 individuals of different sizes. (D) Lanice conchilega; 3 individuals of increasing size show occurrence of double rows of back-to-back uncini from thoracic Segments 11 to 20 . This induces marked increase in number of uncini in tori 

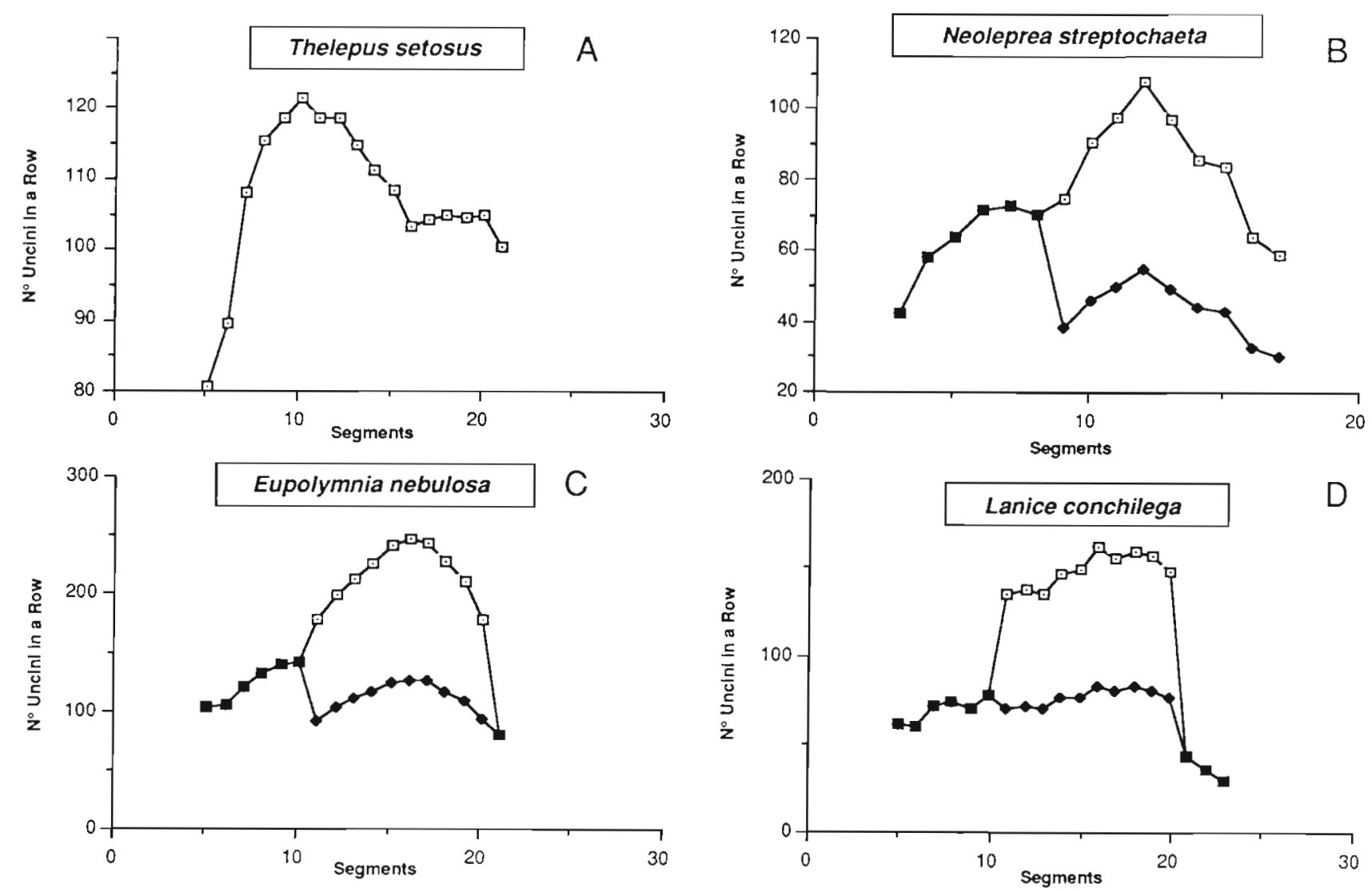

Fig. 6. Relative position of the segment presenting maximum number of uncini per row in 4 species of terebellid polychaetes. Computed values show average number of uncini on tori of every species (average values from 6 Thelepus setosus, 3 Lanice conchilega, 5 Eupolymnia nebulosa and 2 Neoleprea streptochaeta; confidence intervals not shown for clarity). For species with double uncinial rows: total number of uncini given on upper curve, number of uncini on a single row shown on lower curve

by a reduction of the number of alternate doublets. Thus the visible torus appears to be shorter or looser. (2) In $L$. conchilega, the number of uncini on the single rows of the thorax and on the side parts of the alterning torus seem to be rather similar, the alternate production resulting in wider or much denser alternate tori. Uncinial production in the alternate rows is higher than in the corresponding rows of the 2 other species.

\section{CONCLUSIONS}

From observations on plate formation in large polychaete individuals it is deduced that there is a continuous formation of uncinial plates throughout the individual's life. This is true for Thelepus setosus, Eupolymnia nebulosa, Lanice conchilega and Neoleprea streptochaeta, as well as for Pista cretacea and $P$. cristata. The general scheme is the appearance of new uncini on the dorsal side of the torus, with a loss region at the ventral extreme.
There is a decrease in uncinial plate growth rate, seen in the difference in size observed between both extremes of the torus.

Observations dealing with development of the tori within the species reveal several kinds of information. Correlation of the development of the uncinial rows with age in Thelepus setosus shows that the number of added uncini, as well as the size of the uncini, seems to decrease with age. This means that uncinial patterns cannot be accurately used for individual age determination. From the 3rd year on, uncinial sizes reach a plateau with a rather small variability. On the contrary, the variability concerning the number of uncini on a given segment with age is rather high, varying from 120 to 270 uncini on the 8th segment for a 5 yr old individual. It can be seen that, in spite of the existence of solid anatomic parts whose structure is modified during individual growth, there is no visible rhythm that could allow calculation of a reliable growth factor.

Another interesting question is how the transition from larval to adult setal morphology occurs in different 
species. Observations on polychaete larvae reveal that setal position and structure may differ with age. The appearance of early larval setae and the possible occurrence of a new segmentation induce clear variation between larval and adult setal position, and therefore a new numbering. The presence of specialized larval setae disappearing with age, and the presence of newly-formed uncini relative to easily identifiable segments (like branchial segments), show that a development of setal structure occurs within the individual's life span. In Eupolymnia nebulosa, by ca Day 110 thoracic Segments 11 to 20 have formed a torus with a complete set of alterning uncini. The age-related modifications in uncinial pattern of the thoracic tori may lead to taxonomic confusion if one is dealing with specimens for which setal patterns cannot be placed on a sequence of developmental stages. Unfortunately even new species descriptions usually take no account of this role of variability.

\section{LITERATURE CITED}

Bhaud, M. (1979). Les soies des Chaetopteridae. Microscopie électronique à balayage: méthodes d'étude en biologie. Librairie Arnette, Paris, p. 95-98

Bhaud, M. (1988). Growth in natural conditions of Eupolymnia nebulosa (Polychaete, Terebellidae). J. exp. mar. Biol. Ecol. (in press)

Bhaud, M., Grémare, A. (1988a). Reproductive cycle of Eupolymnia nebulosa (Montagu, 1818), Polychaeta, Terebellidae in the western Mediterranean sea. In: Brill, E. J. (ed.) Proc. 2nd int. Polychaete Conference. Ophelia, Leiden (in press)

Bhaud, M., Grémare, A. (1988b). Larval development of the terebellid polychaete Eupolymnia nebulosa. Zool. Scripta 17 : in press

Desbruyères, D. (1976). Cycle biologique de quelques Annélides Polychètes en milieu subantarctique. Thèse 3ème cycle, Univ. P.M. Curie, Paris

Desbruyères, D. (1977). Bionomie benthique du plateau continental des îles Kerguelen. Macrofaune 6 . Evolution des populations de trois espèces d'Annélides Polychètes en milieu subantarctique. CNFRA (Com. nat. fr. Rech. Antarct.) 42: 135-172

Desbruyères, D. (1978). Un Ampharetidae (Annélides Polychètes sédentaires) à structure buccale aberrante: Grathampharete paradoxa gen. sp. n. C. R. Acad. Sci. Paris 286: 281-284

Duchêne, J. C. (1979). Premières données sur la reproduction et la croissance de la Polychète Thelepus setosus en province subantarctique. Annls Inst. océanogr. 55 (2): 145-154

Duchêne, J. C. (1982a). Etude comparée de la biologie d'Annélides Polychètes considérées en différentes zones climatiques. Thèse de Doctorat d'Etat, Océanographie biol., Univ. P. et $M$. Curie

Duchêne, J. C. (1982b). Quelques problèmes liés à la croissance chez les Annélides Polychètes. Séminaire sur la croissance des Invertébrés marins. Océanis 8 (7): 493-504

Duchêne, J. C. (1983). Développement larvaire et fixation chez Thelepus setosus (Annélide Polychète) à Kerguelen, Province subantarctique. Vie Milieu 33 (2): 65-77

Duchêne, J. C. (1985). Adaptation de la reproduction dans les eaux froides en zone subantarctique. Oceanis 11 (2): 87-100

Duchêne, J. C. (1988). Growth rate, fecundity and spawning in two subantarctic populations of Thelepus setosus (Polychaeta: Terebellidae). In: Brill, E. J. (ed.) Proc. of the 2nd Int. Polychaete Conference. Ophelia, Leiden (in press)

Eckelbarger K. G. (1974). Population biology and larval development of the terebellid polychaete Nicolea zostericola. Mar. Biol. 27: 101-113

Escourt, I. (1975). Population structure of Aglaophamus verrilli (Polychaeta: Nephtyidae) from Tasman Bay. N. Z oceanogr Inst. Rec. 2: 149-154

Grémare, A. (1986). A comparative study of reproductive energetics in two populations of the terebellid polychaete Eupolymnia nebulosa (Montagu) with different reproductive modes. J. exp. mar Biol. Ecol. 96: 287-302

Gruet, Y. (1983). Contribution à l'étude de la biologie reproductive dune population naturelle de l'Annélide Polychète Sabellaria alveolata (Linne). Anns. Inst. océanogr. 59 (2): 127-140

Gruet, Y (1986). Premières observations sur la chute des soies operculaires ou palées chez l'Annélide Polychète Sabellariidae Sabellaria alveolata (Linné). C. R. Acad. Sci. 302 (Ser III, 10) 375-378

Herpin, R. (1925). Recherches biologiques sur la reproduction et le developpement de quelques Annélides Polychètes. Bull. Soc. Sci. nat. Quest de la France Ser 4 (5); $1-250$

Holthe, T (1986). Evolution, systematics, and distribution of the Polychaeta Terebellomorpha, with a catalogue of the taxa and a bibliography. Gunneria 55: 1-236

Kirkegaard, J. B. (1970). Age determination of Nephtys (Polychaeta: Nephtyidae). Ophelia 7: 277-282

Lang, F. (1984). Etude de l'activité tentaculaire de Eupolymnia nebulosa Montagu (Annélide polychète): son rôle sur la dynamique de la population et al structuration du peuplement. Océanis 10: 775-784

Olive, P. J. W. (1977). The life-history and population structure of the polychaete Nephtys caeca and Nephtys hombergi with special reference to the growth rings in the teeth. J. mar. biol. Ass. U. K., 57 (1): 133-150

Olive, P. J. W. (1980). Polychaete jaws. In: Rhoads, R. C., Lutz C. R. (eds.) Skeletal growth of aquatic organisms. Plenum Press, New York, p. 501-592

Rétière, Ch. (1976). Détermination des classes d'âge des populations de Nephtys hombergii (Annélides Polychètes) par lecture des mâchoires en microscopie électronique à balayage. Structure des populations en Rance maritime C. R. Acad. Sci. Paris 282 (Ser. D): 1553-1556

Valderhaug, V. A. (1985). Population structure and production of Lumbrineris fragilis (Polychaeta: Lubrineridae) in the Oslofjord (Norway) with a note on metal content of jaws Mar Biol. 86: 203-211 